\title{
Pengujian Kualitas Tanah sebagai Indikator Cemaran Lingkungan di Sekitar Pantai Tanjung Lesung, Banten
}

\author{
Nur Ayu Fitriani a , Ganjar Fadillah b, ${ }^{\text {, }}$, Riri Enriyani ${ }^{\text {a }}$ \\ ${ }^{a}$ Magister Kimia Analitik, Fakultas Matematika dan Ilmu Pengetahuan Alam, Institut Teknologi Bandung \\ ${ }^{\mathrm{b}}$ Analisis Kimia, Fakultas Matematika dan Ilmu Pengetahuan Alam, Universitas Islam Indonesia \\ * corresponding author: ganjar.fadillah@uii.ac.id
}

\begin{tabular}{|c|c|}
\hline ARTIKEL INFO & ABSTRAK \\
\hline $\begin{array}{l}\text { Received : } 05 \text { Juli } 2018 \\
\text { Revised : } 01 \text { Agustus } 2018 \\
\text { Published : } 28 \text { September } 2018 \\
\text { Kata kunci: analisis tanah, } \\
\text { lingkungan, pH, KTK, logam berat }\end{array}$ & $\begin{array}{l}\text { Telah dilakukan penelitian tentang analisis kualitas tanah Tanjung } \\
\text { Lesung, Pandeglang, Banten. Penelitian ini dilakukan secara in } \\
\text { situ dan pengujian lanjut di laboratorium. Berdasarkan hasil } \\
\text { penelitian dan analisis baik secara in situ maupun laboratorium } \\
\text { yang telah dilakukan pada sampel kebun tanah } 1 \text { dan } 2 \text { di daerah } \\
\text { pantai Tanjung Lesung, Kabupaten Pandeglang, diperoleh bahwa } \\
\text { nilai keasaman tanah (pH) berkisar antara 6-7, Kapasitas Tukar } \\
\text { Kation (KTK) diperoleh sebesar } 0,0804 \text { dan } 0,0809 \text { meq/g secara } \\
\text { berturut-turut untuk tanah kebun } 1 \text { dan } 2 \text { serta kandungan logam } \\
\text { berat } \mathrm{Pb}, \mathrm{Cu}, \mathrm{Cd} \text { dan Cr masih memenuhi ambang batas cemaran } \\
\text { lingkungan tanah. Secara keseluruhan kondisi tanah di sekitar } \\
\text { sampling masih memiliki kondisi yang baik dan belum tercemar. }\end{array}$ \\
\hline
\end{tabular}

\section{PENDAHULUAN}

Tanah adalah suatu benda alami heterogen yang terdiri atas komponen-komponen padat, cair, dan gas yang mempunyai sifat serta perlaku yang dinamis. Sedangkan pengertian tanah menurut Bergaya et al., (2006), tanah adalah bahan dasar bagi semua kehidupan di bumi [1]. Campuran penyusun tanah yang kompleks dan subur sangat berperan dalam kehidupan. Tanah adalah lapisan permukaan bumi yang secara fisik berfungsi sebagai tempat tumbuh dan berkembangnya perakaran penopang tumbuh tegaknya tanaman dan menyuplai kebutuhan air dan udara yang secara kimiawi berfungsi sebagai gudang hara dan sebagai sumber penyuplai hara atau nutrisi. Hara atau nutrisi dapat berupa senyawa organik dan anorganik sederhana serta unsur-unsur essensial seperti $\mathrm{N}, \mathrm{P}, \mathrm{K}, \mathrm{Ca}, \mathrm{Mg}, \mathrm{S}, \mathrm{Cu}, \mathrm{Zn}, \mathrm{Fe}$, $\mathrm{Mn}, \mathrm{B}$, dan $\mathrm{Cl}$ ) $[2,3]$. Tanah juga berfungsi sebagai habitat biota (organisme) yang berpartisipasi aktif dalam penyediaan hara tersebut dan zat-zat aditif (pemacu tumbuh, proteksi) bagi tanaman dimana ketiganya secara integral mampu menunjang produktivitas tanah untuk menghasilkan biomass dan produksi baik tanaman pangan, tanaman obat-obatan, industri perkebunan, maupun kehutanan [4].

Begitu banyak kegiatan manusia yang menyebabkan terjadinya kerusakan tanah. Di dalam PP No. 150 th. 2000 disebutkan bahwa "Kerusakan tanah untuk produksi biomassa adalah berubahnya sifat dasar tanah yang melampaui kriteria baku kerusakan tanah". Ketika suatu zat berbahaya atau beracun telah mencemari permukaan tanah, maka ia dapat menguap, tersapu air hujan dan atau masuk ke dalam tanah. Pencemaran yang masuk ke dalam tanah kemudian terendap sebagai zat kimia beracun di tanah [5]. Zat beracun di tanah tersebut dapat berdampak langsung kepada makhluk hidup. Oleh karena itu, untuk mengetahui kerusakan tanah akibat pencemaran maka perlu dilakukan analisis terhadap tanah. Analisis tanah dilakukan untuk mengevaluasi kesuburan lahan serta untuk mengetahui kondisi dan karakteristik tanah, seperti nutrien, kontaminasi, komposisi, keasaman, kandungan mineral dan sebagainya. Berdasarkan hal tersebut, maka penlitian ini perlu dilakukan khususnya untuk mengetahui kualitas tanah di suatu lingkungan. Penelitian dilakukan di daerah pantai Tanjung Lesung yang terletak di ujung barat Pulau Jawa, tepatnya di Desa Tanjung Jaya, Kecamatan Panimbang, Kabupaten Pandeglang, Provinsi Banten. Lokasi ini sangat menarik untuk dikaji kualitas cemaran lingkungannya khususnya pada cemaran tanah dikarenakan daerah tersebut merupakan kawasan wisata yang cukup berkembang dan kepadatan penduduk yang cukup besar. 


\section{METODE}

\subsection{Prosedur Kerja In Situ}

\subsubsection{Waktu dan Tempat Pelaksanaan}

Tahap analisis in situ dilakukan pada tanggal 22 April 2017, sedangkan tahap analisis laboratorium dilaksanakan pada tanggal 28 April 2017. Pelaksanaan pengambilan sampling dilakukan di Pantai Tanjung Lesung yang terletak di ujung barat Pulau Jawa, tepatnya di Desa Tanjung Jaya, Kecamatan Panimbang, Kabupaten Pandeglang, Provinsi Banten. Gambar 1 menunjukan peta lokasi untuk masing-masing sampling tanah pada kebun 1 dan 2 .
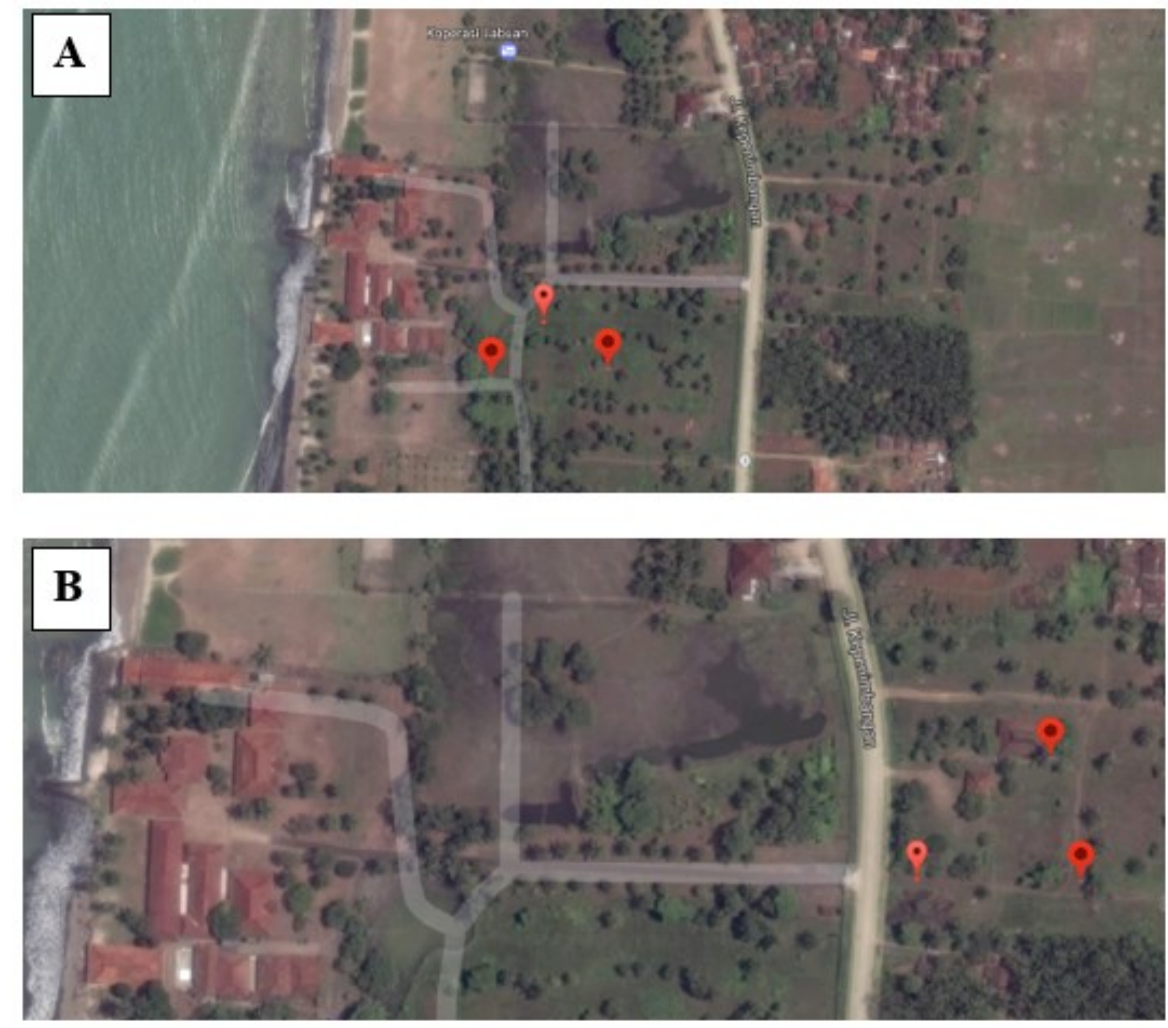

Gambar 1. Lokasi sampling tanah (A) Kebun 1, (B) Kebun 2

\subsubsection{Pengambilan dan Preparasi Sampel Tanah Kebun 1 dan 2}

Pengambilan sampel tanah dilakukan pada dua kebun yang berbeda di sekitar penginapan. Masing-masing tanah kebun diambil pada tiga titik yang berbeda dengan kedalaman kurang lebih 2 $\mathrm{cm}$ menggunakan sendok. Sampel tanah kebun 1 yang telah dikumpulkan kemudian dicampurkan menjadi satu dan diaduk agar homogen. Setelah homogen, sampel tanah kebun 1 dipindahkan ke atas loyang dan dikeringkan di atas hotplate. Sampel tanah kebun 2 diberi perlakuan yang sama seperti sampel tanah kebun 1 .

\subsubsection{Penentuan pH KCl dan $\mathrm{pH} \mathrm{H}_{2} \mathrm{O}$}

Sampel tanah kebun 1 dan 2 ditimbang masing-masing 10 gram dan dimasukkan ke dalam 8 buah botol air mineral plastik ( 2 buah untuk tanah kebun $1 \mathrm{pH} \mathrm{KCl,} 2$ buah untuk tanah kebun $1 \mathrm{pH}$ $\mathrm{H}_{2} \mathrm{O}, 2$ buah untuk tanah kebun $2 \mathrm{pH} \mathrm{KCl}$, dan 2 buah untuk tanah kebun $1 \mathrm{pH} \mathrm{H}_{2} \mathrm{O}$ ). Untuk penentuan $\mathrm{pH} \mathrm{KCl}, 2$ botol berisi tanah kebun 1 dan 2 botol berisi tanah kebun 2 masing-masing ditambahkan $50 \mathrm{~mL} \mathrm{KCl} 1 \mathrm{M}$. Untuk penentuan $\mathrm{pH} \mathrm{H}_{2} \mathrm{O}, 2$ botol berisi tanah kebun 1 dan 2 botol berisi tanah kebun 2 masing-masing ditambahkan $50 \mathrm{~mL}$ air bebas ion. Kedelapan botol dikocok selama 1 jam. Setelah dikocok, didiamkan beberapa menit kemudian disaring dengan kertas saring. $\mathrm{pH}$ filtrat diukur menggunakan $\mathrm{pH}$-meter. Namun, sebelum dilakukan pengukuran, $\mathrm{pH}-$ meter dikalibrasi menggunakan larutan buffer $\mathrm{pH} 4$ dan 7. 


\subsubsection{Penentuan Kapasitas Tukar Kation (KTK) Tanah Kebun 1 dan 2}

Sampel tanah kebun ditimbang sebanyak $10 \mathrm{~g}$ dan dimasukkan ke dalam botol air mineral plastik. Larutan $\mathrm{KCl} 1 \mathrm{M}$ ditambahkan sebanyak $50 \mathrm{~mL}$ ke dalam botol lalu dikocok selama 1 jam. Setelah dikocok, didiamkan beberapa menit kemudian disaring dengan kertas saring. Filtrat dipipet dengan pipet volume $10 \mathrm{~mL}$ lalu dipindahkan ke dalam gelas titrasi. Ke dalam gelas titrasi ditambahkan 3 tetes indikator PP dan air bebas ion untuk mempermudah pengamatan. Setelah itu dilakukan titrasi dengan penitran $\mathrm{NaOH} 0,014 \mathrm{M}$. Titrasi dilakukan hingga terjadi perubahan warna dari tak berwarna menjadi merah muda. Titrasi dilakukan secara duplo. Prosedur yang sama dilakukan untuk sampel tanah kebun 2.

\subsection{Prosedur Kerja Laboratorium}

\subsubsection{Penentuan Faktor Koreksi Kelembaban}

Sampel tanah kebun 1 dan 2 masing ditimbang sebanyak \pm 2 gram pada cawan penguapan yang telah ditentukan bobot kosongnya. Sampel kemudian dipanaskan menggunakan oven pada suhu 100 ${ }^{\circ} \mathrm{C}$ selama 24 jam. Kemudian sampel didinginkan di dalam desikator selama 15 menit dan ditimbang berat cawan dan sampel.

\subsubsection{Pembuatan Larutan Standar $\mathrm{Pb}, \mathrm{Cd}, \mathrm{Cu}$, dan $\mathrm{Cr}(1,2,3,4$, dan 5 ppm)}

Larutan standar $\mathrm{Pb}, \mathrm{Cd}, \mathrm{Cu}$, dan $\mathrm{Cr} 1000 \mathrm{ppm}$ diencerkan menjadi larutan induk 10 ppm. Larutan induk $10 \mathrm{ppm}$ tersebut dipipet sebanyak $1 ; 2 ; 3 ; 4$ dan $5 \mathrm{~mL}$ menggunakan pipet mikro 1000 $\mu \mathrm{L}$ dan dipindahkan ke dalam labu takar $10 \mathrm{~mL}$, kemudian ditambahkan air bebas ion hingga tanda batas dan dihomogenkan.

\subsubsection{Destruksi dan Analisis Sampel Tanah}

Sampel tanah kebin 1 dan 2 yang telah dikeringkan ditimbang sebanyak $0,5 \mathrm{~g}$ dan dimasukkan ke dalam 2 tabung destruksi berbeda. Ke dalam tabung ditambahkan $2 \mathrm{~mL} \mathrm{H}_{2} \mathrm{O}_{2} 30 \%$ dan $6 \mathrm{~mL}$ $\mathrm{HNO}_{3} 65 \%$. Sementara itu, tabung ketiga digunakan sebagai tabung untuk blanko yang berisi $1 \mathrm{~mL}$ air bebas ion, $2 \mathrm{~mL} \mathrm{H}_{2} \mathrm{O}_{2} 30 \%$ dan $6 \mathrm{~mL} \mathrm{HNO}_{3} 65 \%$. Destruksi dilakukan menggunakan Microwave Digestion Sineo pada temperatur $130{ }^{\circ} \mathrm{C}\left(10\right.$ menit), $150{ }^{\circ} \mathrm{C}(5$ menit $), 180^{\circ} \mathrm{C}\left(5\right.$ menit), dan $200{ }^{\circ} \mathrm{C}$ (15 menit). Setelah destruksi, larutan kemudian disaring menggunakan kertas Whatman No.42. Filtrat ditampung di dalam labu takar $25 \mathrm{~mL}$ dan ditambah air bebas ion hingga tanda batas dan dihomogenkan. Larutan sampel kemudian diukur menggunakan SAA. Pada percobaan ini, penentuan kandungan logam di dalam sampel tanah kebun 1 dan 2 dilakukan dengan metode kurva kalibrasi.

\section{HASIL PENELITIAN}

\subsection{Keasaman Tanah}

Berdasarkan hasil pengamatan $\mathrm{pH}$ menggunakan $\mathrm{pH}$ meter, diperoleh nilai pengukuran $\mathrm{pH}$ seperti yang ditunjukan oleh Tabel 1. Penentuan $\mathrm{pH}$ tanah dilakukan pada dua tanah kebun di lokasi yang berbeda. Sampel tanah kebun diperoleh disekitar penginapan pada tiga titik. Pengambilan tiga titik tersebut bertujuan agar sampel tanah yang diperoleh representatif. Selanjutnya masing-masing tanah tersebut diaduk hingga homogen. Tanah yang telah homogen dikeringkan dengan cara pemanasan menggunakan hotplate.

Penentuan $\mathrm{pH}$ tanah dilakukan dengan dua metode. Pertama, tanah dan air dicampurkan, dikocok, kemudian disaring, filtrat yang diperoleh diukur $\mathrm{pH}\left(\mathrm{H}_{2} \mathrm{O}\right)$ nya. Kedua, tanah dan larutan $\mathrm{KCl}$ dicampurkan, dikocok, kemudian disaring, filtrat yang diperoleh diukur $\mathrm{pH}(\mathrm{KCl})$ nya. Penambahan air dan larutan $\mathrm{KCl}$ bertujuan untuk mengekstrak ion $\mathrm{H}^{+}$dalam tanah. Perbandingan antara sampel tanah dan pengekstraknya adalah 1:5. Perbandingan tersebut digunakan agar proses pengekstraksian $\mathrm{H}^{+}$maksimal. Pengocokan bertujuan agar proses ekstraksi $\mathrm{H}^{+}$berlangsung optimal. Pengukuran $\mathrm{pH}$ menggunakan $\mathrm{pH}$ meter.

Pengukuran $\mathrm{pH}$ dilakukan duplo untuk masing-masing sampel tanah kebun 1 dan 2. Nilai $\mathrm{pH}\left(\mathrm{H}_{2} \mathrm{O}\right)$ untuk masing-masing sampel tanah kebun 1 dan 2 berturut-turut adalah 7,580 dan 7,655. Sedangkan nilai $\mathrm{pH}(\mathrm{KCl})$ untuk masing-masing sampel tanah kebun 1 dan 2 berturut-turut adalah 6,845 dan 7,125. pH kedua tanah kebun tersebut bersifat netral. Hal tersebut disebabkan adanya cangkang kerang disekitar tanah kebun 1 dan 2. Cangkang kerang mengandung kalsium karbonat $\left(\mathrm{CaCO}_{3}\right)$ yang tinggi. $\mathrm{CaCO}_{3}$ akan larut dalam air dan mengalami hidrolisis menghasilkan basa kuat dan asam lemah. 


$$
\mathrm{CaCO}_{3}+2 \mathrm{H}_{2} \mathrm{O} \rightleftharpoons \mathrm{Ca}(\mathrm{OH})_{2}+\mathrm{H}_{2} \mathrm{CO}_{3}
$$

Kalsium hidroksida adalah basa kuat yang akan terionisasi menjadi ion $\mathrm{Ca}^{2+}$ dan $\mathrm{OH}^{-}$. Ion $\mathrm{Ca}^{2+}$ menggantikan ion $\mathrm{H}^{+}$yang terserap pada koloid tanah dan ion $\mathrm{H}^{+}$akan bereaksi dengan $\mathrm{OH}^{-}$dengan demikian menetralkan keasaman tanah. Asam karbonat yang terbentuk $\left(\mathrm{H}_{2} \mathrm{CO}_{3}\right)$ tidak stabil dan akan berubah menjadi $\mathrm{CO}_{2}$ dan $\mathrm{H}_{2} \mathrm{O}$. Namun, baik $\mathrm{pH}\left(\mathrm{H}_{2} \mathrm{O}\right)$ dan $\mathrm{pH}(\mathrm{KCl})$ tanah kebun 1 lebih rendah daripada tanah kebun 2. Tanah kebun 2 memiliki pH yang lebih besar disebabkan mendominasinya ion bikarbonat dan karbonat dari kalsium dan magnesium yang dijerap tanah. Sedangkan tanah kebun 1 lebih banyak menjerap ion $\mathrm{Al}^{3+}$ dan $\mathrm{H}^{+}$dibanding tanah kebun 2. $\mathrm{pH}(\mathrm{KCl})$ tanah kebun 1 dan 2 lebih besar dibanding $\mathrm{pH}\left(\mathrm{H}_{2} \mathrm{O}\right)$ tanah kebun 1 dan 2 . Ketika tanah dicampurkan dengan air, sebagian besar ion $\mathrm{H}^{+}$cenderung tetap menempel pada partikel tanah dan tidak dilepaskan ke dalam larutan tanah [6]. Sedangkan penambahan larutan $\mathrm{KCl}$ mengakibatkan pertukaran ion $\mathrm{K}^{+}$dengan ion $\mathrm{H}^{+}$dan $\mathrm{Al}^{3+}$ pada permukaan tanah. Reaksi pertukaran kation $\mathrm{Al}^{3+}$ oleh $\mathrm{K}^{+}$sebagai berikut.

$$
\begin{gathered}
3 \mathrm{X}-\mathrm{AL}^{3+}+3 \mathrm{~K}^{+} \rightleftharpoons \mathrm{X}-\left(\mathrm{K}^{+}\right)_{3}+\mathrm{Al}^{3+} \\
\mathrm{Al}\left(\mathrm{H}_{2} \mathrm{O}\right)_{6}{ }^{3+} \rightleftharpoons \mathrm{Al}\left(\mathrm{OH}^{-}\right) \mathrm{n}\left(\mathrm{H}_{2} \mathrm{O}\right)_{6-\mathrm{n}}+\mathrm{nH}^{+}
\end{gathered}
$$

$\mathrm{Al}^{3+}$ terlarut dalam air mengalami reaksi equilibrium menghasilkan $\mathrm{H}^{+}$. Hal tersebut mengakibatkan jumlah ion $\mathrm{H}^{+}$dalam larutan semakin bertambah sehingga menurunkan $\mathrm{pH}$ dan berpengaruh pada $\Delta \mathrm{pH}$. Hal tersebut yang menyebabkan $\mathrm{pH}(\mathrm{KCl})$ lebih besar dibanding $\mathrm{pH}\left(\mathrm{H}_{2} \mathrm{O}\right)$. Namun, jumlah pelepasan ion $\mathrm{H}^{+}$turun seiring dengan meningkatnya $\mathrm{pH}$ tanah [7]. Hal tersebut ditunjukkan dengan

\begin{tabular}{|c|c|c|c|c|c|c|c|c|c|c|}
\hline \multirow{3}{*}{ Jenis pH } & \multicolumn{5}{|c|}{ Kebun 1} & \multicolumn{5}{|c|}{ Kebun 2} \\
\hline & \multicolumn{2}{|c|}{ Simplo } & \multicolumn{2}{|c|}{ Duplo } & \multirow{2}{*}{$\begin{array}{l}\mathrm{pH} \\
\text { Rata- } \\
\text { rata }\end{array}$} & \multicolumn{2}{|c|}{ Simplo } & \multicolumn{2}{|c|}{ Duplo } & \multirow{2}{*}{$\begin{array}{l}\mathrm{pH} \\
\text { Rata- } \\
\text { rata }\end{array}$} \\
\hline & w (g) & $\mathrm{pH}$ & $\mathrm{w}(\mathrm{g})$ & $\mathrm{pH}$ & & $\mathrm{w}(\mathrm{g})$ & $\mathrm{pH}$ & $\mathrm{w}(\mathrm{g})$ & $\mathrm{pH}$ & \\
\hline $\mathrm{pH}_{\mathrm{H} 2 \mathrm{O}}$ & 10,02 & 7,60 & 10,02 & 7,56 & 7,580 & 10,03 & 7,63 & 10,04 & 7,68 & 7,655 \\
\hline $\mathrm{PH}_{\mathrm{KCl}}$ & 10,01 & 6,83 & 10,06 & 6,86 & 6,845 & 10,05 & 7,14 & 10,01 & 7,11 & 7,125 \\
\hline Selisih & \multicolumn{4}{|c|}{ Netral } & 0,740 & \multicolumn{4}{|c|}{ Netral } & 0,530 \\
\hline
\end{tabular}
$\Delta \mathrm{pH}$ tanah kebun $2(0,530)$ lebih kecil daripada $\Delta \mathrm{pH}$ tanah kebun $1(0,740)$.

TABEL 1. Hasil pengukuran $\mathrm{pH}$ tanah

Konsentrasi $\mathrm{H}^{+}$yang diekstrak dari tanah kebun $1=10^{-\mathrm{pH}}=10^{-0,735}=0,1820 \mathrm{M}$

Konsentrasi $\mathrm{H}^{+}$yang diekstrak dari tanah kebun $1=10^{-\mathrm{pH}}=10^{-0,530}=0,2951 \mathrm{M}$

\subsection{Kapasitas Tukar Kation (KTK)}

Kapasitas tukar kation (KTK) merupakan parameter tanah yang merepresentasikan kemampuan tanah untuk menarik, mempertahankan dan menahan kation yang dapat dipertukarkan. Berdasarkan data dan perhitungan, $\mathrm{pH} \mathrm{H}_{2} \mathrm{O}$ sampel tanah kebun 1 adalah 7,58 yang menunjukkan bahwa $\left[\mathrm{OH}^{-}\right]$ pada sampel tanah kebun 1 sedikit lebih besar dibandingkan dengan $\left[\mathrm{H}^{+}\right]$dengan acuan bahwa $\mathrm{pH}$ dari air ultrapure mendekati 7. Pada saat dilakukan pengukuran $\mathrm{pH} \mathrm{KCl}$ pada sampel tanah kebun 1 diperoleh $\mathrm{pH}$ sebesar 6,845. Hal ini menunjukkan bahwa sampel tanah kebun 1 bersifat asam setelah dilarutkan ke dalam $\mathrm{KCl}$ karena terjadinya peningkatan $\left[\mathrm{H}^{+}\right]$yang disebabkan oleh pertukaran ion $\mathrm{K}^{+}$dari $\mathrm{KCl}$ dengan ion $\mathrm{H}^{+}$yang berasal dari sampel tanah kebun 1 . Adanya ion $\mathrm{H}^{+}$dari sampel tersebut dapat diakibatkan oleh adanya asam-asam organik dan anorganik yang dihasilkan oleh penguraian bahan organik tanah. Selain itu, respirasi akar tanaman dalam tanah menghasikan $\mathrm{CO}_{2}$ yang akan bereaksi dengan air yang ada di dalam tanah menghasilkan $\mathrm{H}_{2} \mathrm{CO}_{3}[8]$

Prosedur Kapasitas Tukar Kation (KTK) untuk sampel tanah kebun 2 sama dengan prosedur yang digunakan pada sampel tanah kebun 1. Sampel tanah kebun 2 memiliki $\mathrm{pH}_{2} \mathrm{O}$ sebesar 7,655 yang menunjukkan bahwa $\left[\mathrm{OH}^{-}\right]$pada sampel tanah kebun 2 sedikit lebih besar dibandingkan dengan $\left[\mathrm{H}^{+}\right]$ dengan acuan bahwa $\mathrm{pH}$ dari air ultrapure mendekati 7. Pada saat dilakukan pengukuran $\mathrm{pH} \mathrm{KCl}$ diperoleh $\mathrm{pH}$ sebesar 7,125. Hal ini menunjukkan bahwa sampel tanah kebun 2 bersifat basa yang sangat lemah.

Copyright (c) 2018, Indonesian Journal of Chemical Analysis, ISSN 2622-7401, e ISSN 2622-7126 
Berdasarkan hasil perhitungan diperoleh bahwa nilai KTK pada kebun 1 dan 2 secara berurutan sebesar $0,0804 \mathrm{meq} / \mathrm{g}$ untuk sampel tanah kebun 1 dan $0,0809 \mathrm{meq} / \mathrm{g}$ untuk sampel tanah kebun 2. Nilai KTK yang didapatkan relatif besar sehingga dapat dikatakan bahwa ion $\mathrm{K}^{+}$yang dipertukarkan dengan ion $\mathrm{H}^{+}$yang ada di dalam tanah cukup besar. Nilai KTK untuk sampel tanah kebun 2 sedikit lebih besar dibandingkan dengan sampel tanah kebun 1 disebabkan ketiga titik lokasi pengambilan sampel pada tanah kebun 2 memiliki kandungan tanah liat yang lebih banyak dibandingkan tanah kebun 1 dan nilai $\mathrm{pH}$ tanah kebun 2 lebih besar dari tanah kebun 1. Semakin asam $\mathrm{pH}$ suatu tanah maka bahan organik dalam tanah akan kehilangan kemampuannya untuk mempertahankan kation. Hal ini menyebabkan nilai KTK tanah kebun 2 lebih besar dibandngkan tanah kebun 1.

\subsection{Kandungan Logam Berat $\mathrm{Pb}, \mathrm{Cd}, \mathrm{Cu}$ dan $\mathrm{Cr}$}

Analisis kandungan logam berat pada sampel pada umumnya dilakukan terlebih dahulu preparasi sampel melalui destruksi basah. Proses destruksi ini bertujuan untuk memecah senyawa menjadi unsur-unsurnya sehingga dapat dianalisis atau disebut juga perombakan, yaitu dari bentuk organik logam menjadi bentuk logam-logam anorganik. Pada percobaan ini, destruksi dilakukan dengan menggunakan Microwave Digestion menggunakan pelarut campuran antara $\mathrm{HNO}_{3}$ dan $\mathrm{H}_{2} \mathrm{O}_{2}$. Penambahan $\mathrm{H}_{2} \mathrm{O}_{2}$ ditujukan untuk mendestruksi materi organik dan mengoksidasi sulfida menjadi sulfat sementara $\mathrm{HNO}_{3}$ digunakan untuk mengoksidasi bahan material yang terkandung di dalam sampel tanah [9]. Penggunaan $\mathrm{HNO}_{3}$ sebagai pelarut destruksi ini cukup efisien karena dapat melarutkan banyak logam yang terkandung di dalam tanah. Sebagai contoh, penelitian sebelumnya melaporkan bahwa asam nitrat dapat mengoksidasi logam $\mathrm{Cr}$ ke dalam bentuk $\mathrm{Cr}^{2+}$ yang memiliki kelarutan yang lebih tinggi. Reaksi ditunjukan sebagai berikut:

$$
3 \mathrm{Cr}(\mathrm{s})+8 \mathrm{HNO}_{3}(\mathrm{aq}) \rightarrow 3 \mathrm{Cr}^{2+}(\mathrm{aq})+6 \mathrm{NO}^{3-}(\mathrm{aq})+2 \mathrm{NO}(\mathrm{g})+4 \mathrm{H}_{2} \mathrm{O}(\mathrm{l})
$$

Hasil pengukuran dengan SSA menggunakan teknik metode kalibrasi diperoleh bahwa kandungan logam berat yang memiliki nilai $>1$ ppm hanyalah logam $\mathrm{Pb}$ sementara untuk logam $\mathrm{Cu}, \mathrm{Pb}$ dan $\mathrm{Cr}$ konsentrasi di dalam tanah $<1 \mathrm{ppm}$. Jika dibandingkan dengan standar baku kandungan logam berat $\mathrm{Pb}$ di dalam tanah yaitu berkisar 2-200 ppm [10], maka kandungan logam berat $\mathrm{Pb}$ yang diperoleh dari hasil analisa yaitu sebesar 8,84 ppm baik pada sampel tanah kebun 1 dan 2 masih memenuhi standar baku mutu. Jika meninjau dari lokasi sampling yang terletak disepanjang jalur utama kendaran bermotor, maka diperolehnya kandungan $\mathrm{Pb}$ di dalam sampel tanah tersebut bisa jadi dikarenakan cemaran dari emisi kendaran bermotor yang menghasilkan logam $\mathrm{Pb}$ dari pembakaran yang tidak sempurna. Karena senyawa $\mathrm{Pb}$ ini tidak mudah larut di dalam air, tidak mengalami penguapan, tidak mengalami degradasi dan tidak mudah dihancurkan sehingga logam $\mathrm{Pb}$ ini dapat terakumulasi di dalam tanah [11]. Pada dasarnya, logam $\mathrm{Pb}$ tidak akan larut ke dalam tanah jika tanah tidak bersifat asam. Jika meninjau dan mengkorelasikan dengan hasil $\mathrm{pH}$, maka hasil kandungan logam $\mathrm{Pb}$ di dalam tanah sangat berkorelasi.

\section{KESIMPULAN}

Berdasarkan hasil percobaan dan analisis baik secara in situ maupun laboratorium yang telah dilakukan pada sampel kebun tanah 1 dan 2 di daerah pantai Tanjung Lesung, Kabupaten Pandeglang. Maka dapat disimpulkan bahwa parameter uji yang telah dilakukan meliputi keasaman tanah (pH), Kapasitas Tukar Kation (KTK) dan kandungan logam berat $\mathrm{Pb}, \mathrm{Cu}, \mathrm{Cd}$ dan $\mathrm{Cr}$ masih memenuhi ambang batas cemaran lingkungan tanah. Secara pengamatan lapangan, nilai $\mathrm{pH}$ yang berkisar antara 6-7 dikarenakan pada lokasi sampling banyak terdapat cangkang kerang sehingga mempengaruhi kondisi keasaman tanah karena terurainya $\mathrm{CaCO}_{3}$ oleh air. Sedangkan kandungan logam $\mathrm{Pb}$ yang mencapai 8,84 ppm dikarenakan lokasi sampling berada pada jalur utama kendaraan bermotor yang memungkinkan cemaran dari pembakaran tidak sempurna dari kendaraan bermotor. Namun, secara keseluruhan kondisi tanah di sekitar sampling masih memiliki kondisi yang baik dan belum tercemar. 


\section{Daftar Pustaka}

[1] G. Bergaya, and B. K. G., Lagaly, "Handbook of Clay Science, Developments in Clay Science," Amsterdam, Elsevier, p.p. 979-1001, 2006.

[2] H. D. Foth, “Fundamentals of Soil Science,” John Wiley \&amp; Sons. Inc., Canada, 1990.

[3] W., Friesl, E., Lombi, O., Horak, and W., Wenzel, "Immobilization of heavy metals in soils using inorganic amendments in a greenhouse study," Journal of Plant Nutrition and Soil Science, vol 166, pp 191-196, 2003.

[4] A. Kabata-Pendias, and H., Pendias, "Trace Elements in Soils and Plants," CRC Press, Boca Raton, FL, 1992.

[5] Soil Science Society of America. Soil Overview. 2015

[6] Gavriloaiei, "The Influence of Electrolyte Solutions on Soil pH Measurements," Revista de Chimie -Bucharest- Original Edition, pp. 396-400, 2012

[7] R.O., Miller, and D. E., Kissel, "Comparison of Soil pH Methods on Soils of North America," Soil Science Society of America Journal, vol 74, pp. 310-316, 2010.

[8] Q., Wang, Y., Li, and W., Klassen, "Determination of Cation Exchange Capacity on Low to Highly Calcareous Soils," Communications in Soil Science and Plant Analysis, vol. 36, pp. 1479-1498, 2005.

[9] S. P., McGrath, and C. H., Cunliffe, "A simplified method for the extraction of the metals Fe, $\mathrm{Zn}, \mathrm{Cu}, \mathrm{Ni}, \mathrm{Cd}, \mathrm{Pb}, \mathrm{Cr}, \mathrm{Co}$ and $\mathrm{Mn}$ from soils and sewage sludges," Journal Science Food Agriculture, vol. 36, pp. 794-798, 1985

[10] Standar Nasional Indonesia, "Penentuan Kadar $\mathrm{Pb}, \mathrm{Cu}, \mathrm{Zn}, \mathrm{Fe}, \mathrm{Mn}$, dan $\mathrm{Cd}$ dengan Spektrofotometer Serapan Atom (SSA)," SNI 13-6974, 2003.

[11] N. T., Basta, and S. L., McGowen, "Evaluation of chemical immobilization treatments for reducing heavy metal transport in a smelter-contaminated soil," Environmental Pollution, vol. 127, pp. 73-82, 2004 